\title{
Az új-zélandi muszlimellenes terrortámadás és tanulságai
}

\begin{abstract}
Jelen írás a 2019. márciusi új-zélandi Christchurchben elkövetett terrortámadást elemzi. Elsősorban arra hívja fel a figyelmet, hogy az elkövető az egész akciót úgy építette fel, hogy a lehető legnagyobb láthatóságot érje el. A szerzők úgy vélik, hogy az ilyen típusú terrortámadások a jövőben megszaporodhatnak, mert nem kizárható, hogy a christchurchi elkövetö - akit a norvég Anders Breivik inspirált - másokat is hasonló terrorcselekményekre ösztönöz. Az iszlámellenes terrortámadásokban mára trenddé vált, hogy az elkövetők muszlim vallási intézményeket támadnak, ugyanis így a legnagyobb az esély rá, hogy specifikusan muszlimokat tudjanak ölni.
\end{abstract}

Kulcsszavak: terrorizmus, Új-Zéland, muszlimellenesség, Anders Breivik, Brenton Tarrant

Tálas Péter - Rácz András - Ambrus Andrea: New Zealand's Anti-Muslim Terrorist Attack and Lessons Learned

This article analyses the March 2019 terrorist attack in Christchurch, New Zealand. First of all, it points out that the perpetrator has designed the entire action in such a way as to gain the greatest possible visibility. The authors' opinion is that this type of terrorist attacks may increase in the future, because it cannot be ruled out that the Christchurch perpetrator, inspired by Anders Breivik of Norway, will induce others to commit similar terrorist acts. In terrorist attacks against Islam, it has become a trend for perpetrators to attack Muslim religious institutions, with the greatest chance of being able to specifically kill Muslims.

Keywords: terrorism, New Zealand, islamophobia, Anders Breivik, Brenton Tarrant

\section{Bevezetés}

A 2019. március 15-én az új-zélandi Christchurchben elkövetett terrortámadás - a támadó szándékának megfelelően - várhatóan stratégiai hatást ér majd el. Elsősorban azért, mert az elkövető, Brenton Tarrant az egész akciót úgy építette fel, hogy a lehető legnagyobb láthatóságot érje el, ideértve a szimbolikus nevü helyszín kiválasztását, 74 oldalas manifesztumának közreadását, illetve a támadás élő internetes közvetítését is. Másodsorban azért, mert a történtek újra rávilágítanak a muszlim és nem muszlim közösségek közötti együttélés kérdéseire, további súlyos indulatokkal terhelve azt. Annál is inkább, mert Tarrant magát az iszlám elleni globális harc részének tekinti, és nemcsak korábbi történelmi elődök erősen torzított értelmezésű példáját igyekezett követni, hanem egyértelműen másokat is erre akart sarkallni. Harmadrészt pedig azért, mert nem zárható ki sem az, hogy Tarrant 
akciója másokat is hasonló támadásokra motivál, sem pedig az, hogy az új-zélandi támadás bosszúakciókra ösztönöz majd radikális dzsihádistákat.

A támadás emellett arra is rávilágít, hogy mennyire kiemelt fontosságú, hogy ilyen helyzetekben a rendőrség a lehető legrövidebb időn belül tudjon reagálni. Új-Zélandon ez nem kevesebb, mint 36 (!) percbe tellett, a fóvárostól 440 kilométerre fekvő, lakosságszámát tekintve a harmadik legnagyobb új-zélandi városban. Ennyi idő alatt pedig a katonailag egyébként képzetlen támadó is súlyos károkat tudott okozni, nem utolsósorban azért, mert a helyi liberális fegyvertartási szabályok miatt több fegyvere és óriási mennyiségű lőszere is volt.

\section{Az elkövetés módja}

Az ausztrál származású, Új-Zélandon élő, 28 éves Brenton Tarrant 2019. március 15-én a 440 ezer lakosú Christchurch városában kézifegyverekkel megtámadta a helyi muszlim közösség két mecsetjét. Elöször az Al Núr mecsetben ölt meg összesen 42 embert, majd autóval áthajtott a közeli Linwood mecsetbe, és ott további hét emberrel végzett. A sebesültek száma 51 fö volt (egy ember azonban a kórházban belehalt sérüléseibe), közülük többen súlyos, kritikus állapotban kerültek kórházba.

A támadás során Tarrant átalakított félautomata fegyvereket használt, így azokkal sorozatot is tudott lőni. A merényletet követően néhány nappal az új-zélandi kormány be is jelentette, hogy néhány kivétellel betiltja a félautomata fegyverek, valamint a külső, cserélhető tárral rendelkező puskák birtoklását, vásárlását és használatát. Emellett fegyvervisszavásárlási program is indult. ${ }^{1}$

A rendelkezésre álló információk szerint Tarrant közel két éve készült a támadásra. Gondos tervet készített, többször is felmérte mindkét mecsetet, fegyvereket vásárolt, sőt, még egy európai körutazásra is elment, hogy ihletett merítsen a muszlimok elleni európai történelmi küzdelem sikereiből. Emellett egy hosszú, 74 oldalas politikai manifesztumot is készített, The Great Replacement címmel, amelyet a 4chan-en tett közzé, a támadás előtti este. ${ }^{2}$ A kétéves felkészülési folyamat során Tarrant mindvégig el tudta kerülni, hogy a hatóságok látókörébe kerüljön.

Abban, hogy a merényletnek nem lett több áldozata, több szerencsés körülmény is szerepet játszott. Egyrészt, az első támadást Tarrant félbeszakította, és - vagy a fegyvere hibája miatt, vagy lőszerhiány miatt - visszament a közelben parkoló kocsijához, fegyvert cserélt, majd visszament a mecsetbe, folytatni a gyilkolást. Ez a néhány percnyi haladék sokak számára a menekülés esélyét jelentette. Másrészt, terrortámadások során egyébként szokatlan módon Tarrant kétszer is ellenállásba ütközött az áldozatok részéről. Először az ötvenéves, pakisztáni származású Najím Rasid megpróbálta kicsavarni a fegyvert Tarrant kezéből, ám őt a terrorista agyonlőtte. Másodjára pedig az Afganisztánból érkezett, 48 éves Abdul Aziz támadt rá, egyéb eszköz híján először hozzávágva egy bankkártyaolvasót, majd pedig

\footnotetext{
Alex Horton: 'This is what leadership looks like': U.S. Democrats Rally and New Zealand bans military-style guns, [online], 2019. 03. 21. Forrás: washingtonpost.com [2019. 03. 22.]

2 Tom Porter: Someone claiming to be the New Zealand mosque gunman posted a racist manifesto online before the attack, [online], 2019. 03. 15. Forrás: theinsider.com [2019. 03. 22.]
} 
miután sikerült elkerülnie Tarrant lövéseit, a korábban eldobott fegyvert Tarrant kocsijának dobva betörte annak szélvédőjét. A törött szélvédő később nagyon megkönnyítette a rendőrök számára az elkövető autójának azonosítását. A két férfi hősies ellenállása minden bizonnyal számos életet mentett meg, és nélkülük a támadás még több áldozattal járt volna.

A támadást Tarrant mindvégig élőben szándékozott közvetíteni az interneten. Noha a közvetítés az első támadás után megszakadt, a 17 perces videó példátlan karriert futott be a világhálón: a merényletet követő első 24 órában csak a Facebook közösségi hálózat másfél millió alkalommal távolította el a felvételt saját platformjáról, de az ennek ellenére terjed tovább. ${ }^{3}$ A támadó célja ezzel deklaráltan az volt, hogy másokat is saját példája követésére buzdítson.

Az akció előtt kilenc perccel Tarrant több mint 30 helyre elküldte ugyan saját, 74 oldalas manifesztumát (többek között az új-zélandi miniszterelnöki hivatalba, számos médiához és a rendőrségre is), azonban a hatóságok nem tudtak mit kezdeni vele, mert az e-mail nem tartalmazott konkrétumot. Így aztán, mivel előzetesen nem rendeltek el riasztást vagy magasabb készenléti szintet, végül 36 (!) percbe tellett, amíg az első rendőrök a támadás helyszínére értek. Ez különösen annak fényében rossz adat, hogy a 2017-es londoni terrortámadások idején a rendőrség tipikusan 8-10 percen belül már semlegesíteni tudta a támadókat, és megkezdődhetett a sérültek ellátása. ${ }^{4}$

Miután pedig a rendőrség kiérkezett és üldözőbe vette, Tarrant megpróbált ugyan menekülni, de tevőlegesen nem állt ellen. Érzékelhetően az volt a szándéka, hogy túlélje az elfogást. Az pedig, hogy ezután kétszer is elutasította a kirendelt védőt, ehelyett pedig saját magát kívánja védeni a bíróságon, azt valószínüsíti, hogy igyekszik majd a pert is felhasználni saját nézetei további terjesztésére.

\section{Korábbi támadások a muszlim kisebbség ellen a nyugati országokban}

Az elmúlt években egyre több a muszlimok ellen elkövetett támadás, de az új-zélandi mecsetek ellen elkövetett támadás volumenéhez képest csak egyszerübb, jelentősen kevesebb halálos áldozatot követelő merényletekről beszélhetünk. Egy drezdai tárgyalóteremben 2009-ben bírósági tanúvallomás során halálra késeltek egy muszlim nőt, és súlyosan megsebesítették a férjét. A terhes nőt 16 alkalommal szúrta meg a támadója, Alex Wiens, akit később életfogytig tartó börtönbüntetésre ítéltek. ${ }^{5}$ Londonban, 2017 júniusában egy autó hajtott a járókelők közé a Finsbury Park mecsetjénél, 10 ember megsérült és a gázolásnak

Jennifer FAULL: Facebook removed 1.5m videos of Christchurch attacks within 24 hours, [online], 2019. 03. 17. Forrás: thedrum.com [2019. 03. 20.]

4 Reiss Smith et al.: London terror attack TIMELINE: 4 dead and 29 injured after major incident at Westminster, [online], 2017. 03. 23. Forrás: express.co.uk [2019. 03. 24.]; Winterbotham, Emily: The Westminster attack shows the new challenges facing UK counter-terrorism, [online], 2017. 03. 24. Forrás: theguardian.com [2019. 03. 23.]

5 Martin Schlicht: German jailed for life for stabbing Egyptian woman, [online], 2009. 11. 11. Forrás: reuters.com [2019. 03. 16.] 
egy halálos áldozata is volt. Az elkövető, Darren Osborne, egy erőszakra hajlamos, mentális problémákkal küzdő munkanélküli férfi, aki később életfogytiglani börtönbüntetést kapott. ${ }^{6}$ Az egyik legtöbb áldozatot követelő muszlimok elleni támadást 2017 januárjában, a kanadai Quebec városában követték el. Egy fegyveres támadó, Alexandre Bissonnette az imára gyűlő tömegbe lőtt az iszlám kulturális központ mecsetjénél. A támadás során hat ember vesztette életét. Az elkövetőnek bár voltak mentális problémái, nem vallotta magát sem terroristának, sem iszlamofóbnak - ugyanakkor azt mondta, hogy „félelem, negatív gondolatok és szörnyü kétségbeesés kísértette" ${ }^{7}$

A fentieken kívül több, halálos áldozatokkal nem járó incidens is történt, köztük mecsetek és személyek elleni támadások egyaránt. Párizsban, 2017 júniusában, egy mecset előtti tömegbe próbált autóval belehajtani egy férfi, bosszúból a 2015. novemberi párizsi terrortámadásért. ${ }^{8}$ Spanyolországban a barcelonai támadások után szintén megfigyelhető volt a muszlimok ellen elkövetett támadások számának emelkedése: több spanyol város mecsetjein megjelentek fenyegető feliratok, fiatalokat és nőket is értek támadások. ${ }^{9}$ A bevándorlók vagy épp vallási csoportok ellen irányuló félelemkeltés is az egyik oka lehet az ilyen jellegü támadásoknak. Több nyugat-európai országban megfigyelhető tendencia, hogy a muszlimok elleni verbális és fizikai támadások száma is emelkedett, továbbá a célpontokat elemezve megállapítható, hogy a leggyakoribbak - logikus módon - a mecsetekben és azok közvetlen környékén elkövetett támadások. Ezzel együtt léptékében, az áldozatok számában és globális médiavisszhangjában az új-zélandi támadás egyedülálló.

A legutóbbi, christchurchi támadás nyomán immár jól megfigyelhető trend, hogy a terroristák felismerték: specifikusan muszlimokat gyilkolni úgy tudnak a legbiztosabban, ha olyan intézményeket támadnak, ahol lényegében kizárólag muszlim áldozatok lesznek. Az eddigi támadások jellemzően mecseteket értek, de a jövőben nem zárhatók ki a madraszák (iszlám vallásos iskolák) elleni támadások sem, annál is inkább, mert ezek jellemzően kevesebb védelmet, illetve figyelmet élveznek a hatóságok részéről.

\section{Terrorizmus Új-Zélandon}

Új-Zélandon az utóbbi időben egyáltalán nem került sor halálos merényletre. A mostani terrortámadás helyiértékét jól jelzi, hogy Üj-Zélandon a terrorizmus 2001-től számított, úgynevezett posztmodern korszakában elkövetett 11 merényletnek nem voltak sem halálos, sem pedig sebesült áldozatai. A terrorizmus a tágabban vett térséget is viszonylag megkímélte: a régióban 2000 és 2018 között elkövetett 77 merényletnek a Global Terrorism

6 Michael Holden: Man who drove van into London mosque worshippers jailed for 43 years, [online], 2018. 02.02. Forrás: reuters.com [2019. 03. 16.]

Andy Riga: 'What I did is unforgivable', Quebec mosque shooter says after pleading guilty, [online], 2018. 03.28. Forrás: montrealgazette.com [2019. 03. 18.]

8 Paris mosque: Man held after 'trying to ram crowd with vehicle', [online], 2017. 06. 29. Forrás: bbc.com [2019. 03. 18.]

9 Stop Islamophobia, [online], 2017. 08. 25. Forrás: elpais.com [2019. 03. 18.] 
Database adatai szerint mindössze 20 halálos és 53 sebesült áldozata volt. ${ }^{10}$ Tény ugyanakkor, hogy a szomszédos Délkelet-Ázsiában elkövetett merényleteknek számos térségbeli áldozata volt (csak a 2002-es bali robbantásnak 88 ausztrál és 2 új-zélandi). Új-Zélandon egyébként utoljára halálos áldozatot követelö terrorista merényleteket az 1980-as években követtek el. 1982. november 18-án - a lakosság személyes adatainak számítógépeken történő rögzítése elleni tiltakozásként - a 22 éves aucklandi anarchista, Neil Roberts követett el öngyilkos merényletet a Wanganui Számitástechnikai Központ bejáratánál, ${ }^{11} 1984$. március 24-én pedig a Wellingtoni Mesterek Csarnoka előtt robbantott bombát egy máig ismeretlen elkövetö, megölve egy embert. ${ }^{12} \mathrm{Az}$ eddigi legismertebb „új-zélandi” politikai merénylet a Greenpeace nemzetközi környezetvédő szervezet Rainbow Warrior nevü hajójának francia titkosszolgálat (DGSE) általi elsüllyesztése volt 1985. július 10-én. Az Ördögi Hadművelet (Opération Satanique) kódnevet viselő műveletnek egy portugál-holland halálos áldozata volt. ${ }^{13}$ Összességében tehát Ưj-Zéland a világ legkevésbé terrorfenyegetett térségei közé tartozott, egészen 2019. március 15-éig.

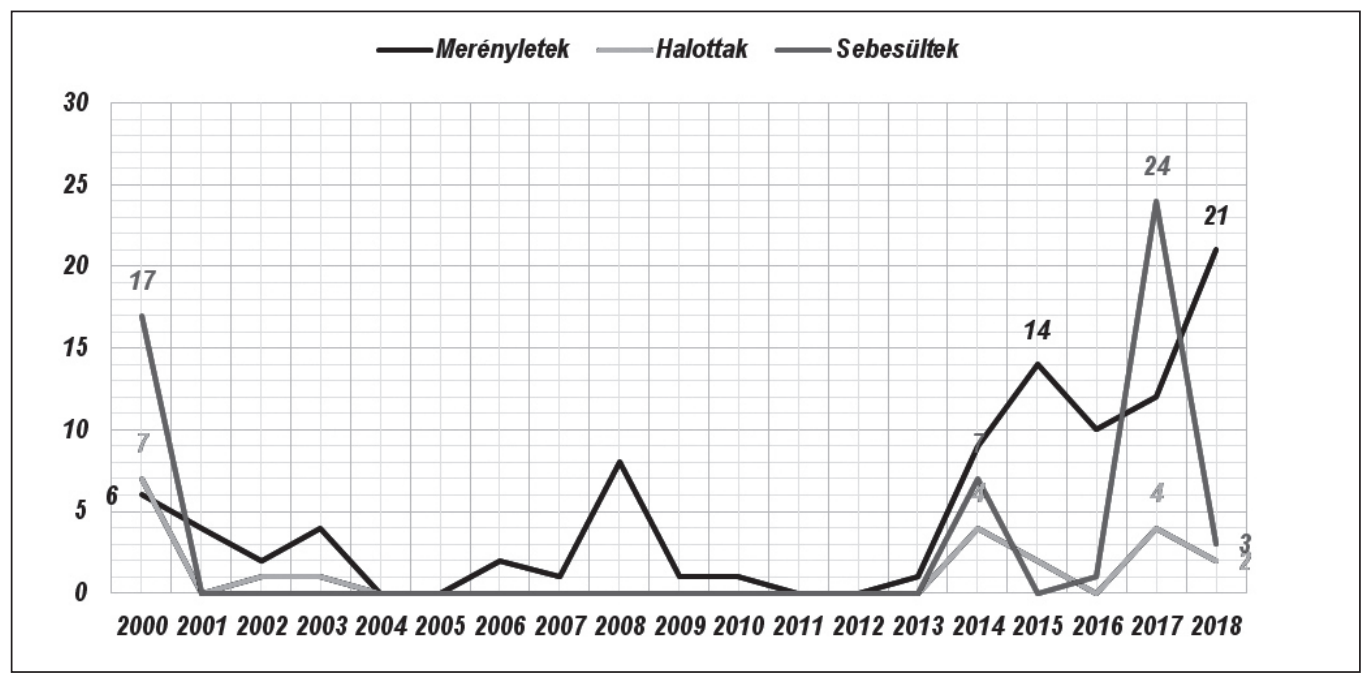

1. ábra: Terrorcselekmények és áldozataik Ausztráliában és Óceániában 2000-2018

Forrás: Global Terrorism Database

102000 és 2018 között Ausztráliában 48 merényletet (11 halott és 33 sebesült), Új-Zélandon 11 merényletet (áldozatai nem
voltak), Pápua Új-Guineában 10 merényletet ( 3 sebesült áldozat), a Fidzsi-szigeteken 5 merényletet (7 halott és 17 sebe-
sült), a Salamon-szigeteken pedig 3 merényletet ( 2 halott) követtek el.
Bomb damage to the Wanganui Computer Centre, 1982, [online], 2012. 06. 20. Forrás: teara.govt.nz [2019. 03. 15.]
12 Tom HunT: Trades Hall bombing tragedy still an unsolved mystery, [online], 2016. 03. 30. Forrás: stuff.co.nz [2019. 03. 15.]
13 John Armstrong: Reality behind the Rainbow Warrior outrage, [online], 2005. 07. 02. Forrás: nzherald.co.nz [2019. 03. 15.] 


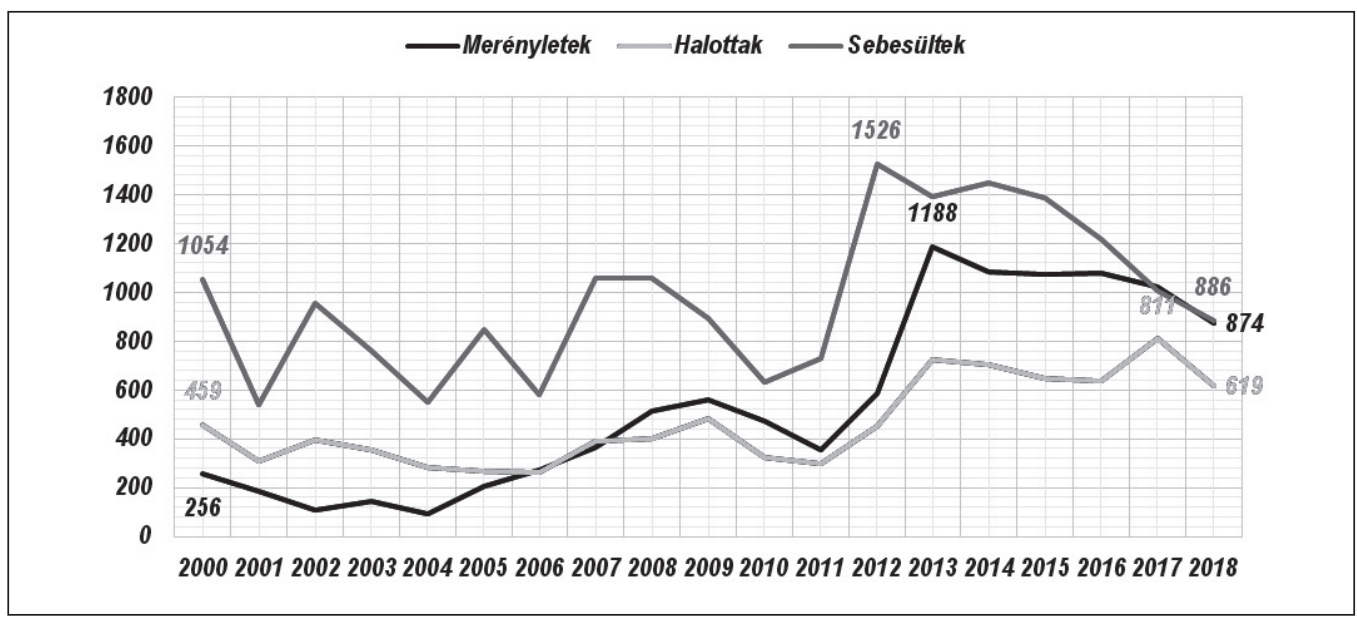

2. ábra: Terrorcselekmények és áldozataik Délkelet-Ázsiában 2000-2018

Forrás: Global Terrorism Database

\section{Az új-zélandi muszlim közösség}

A christchurchi támadást egyértelműen iszlámellenes indíttatásból követték el. Bár ÚjZélandon közel száz éve élnek muszlimok, a 4,8 milliós ország lakosságának napjainkban is csupán 1\%-át teszik ki (a 2013. évi népszámláláskor 46 ezer volt a számuk). ${ }^{14} \mathrm{~A}$ muszlim kisebbség jelenleg 57 mecsettel és egyéb közösségi létesítménnyel rendelkezik az országban. Tény azonban, hogy arányuk az elmúlt időszakban az egyéb népcsoportokhoz képest dinamikusabban nött, 2006 és 2013 között 28\%-kal, miközben a magukat kereszténynek tekintők aránya csökkent az összlakosságon belül (2001 és 2013 között 60\%-ról 48,9\%-ra). A 2013-as népszámlálás adatai szerint az új-zélandi muszlimok mintegy negyede már az országban született. ${ }^{15} \mathrm{~A}$ demográfiai előrejelzések szerint, ha fennmarad jelenlegi növekedési arányuk, 2030-ra létszámuk megduplázódhat. ${ }^{16}$

Fontos jelezni, hogy bár a szakértők szerint az Új-Zélandon élő muszlim fiatalok a jól integrálódó közösségekhez tartoznak, legalábbis maori vagy európai társaikkal összevetve, a helyi lakosság jóval nagyobb fenntartásokkal tekint rájuk, mint a Kínából vagy Fülöp-szigetekről érkezőkre. ${ }^{17}$ A New Zealand Herald egy 2015-ös felmérése szerint a muszlimok annak ellenére is nehezebben jutnak álláshoz, hogy a más vallásúakhoz képest általában magasabb az iskolai végzettségük. ${ }^{18}$ Jóllehet Új-Zélandot befogadó országként tartja számon a nemzetközi közvélemény, az állam migrációs törvényei - hasonlóan

142013 Census QuickStats about culture and identity, [online], 2014. 04. 15. Forrás: stats.govt.nz [2019. 03. 15.]

152013 Census QuickStats about culture and identity, [online], 2014. 04. 15. Forrás: stats.govt.nz [2019. 03. 15.]

16 Yaghoob Foroutan: Muslim Minority of New Zealand in Global Context: Demographic Perspective, Journal of Muslim Minority Affairs, 37. évf. 2017/4, 511-519. o.

17 Facts about New Zealand's Muslim minority - a mere 1pc of the population, [online], 2019. 03. 15. Forrás: dawn.com [2019. 03. 15.]

18 TAN, Lincoln: The state of faith: Muslims most likely to be unemployed, [online], 2015. 05. 14. Forrás: nzherald.co.nz [2019. 03. 15.] 
Ausztráliához - erősen restriktívek. A wellingtoni kormányzat például kizárólag az Egyesült Nemzetek Menekültügyi Főbiztoságának (UNHCR) keretei között hajlandó menekülteket befogadni. Igaz ugyanakkor, hogy a jelenlegi kormányfö, Jacinda Ardern, épp 2018 szeptemberében egyezett bele a befogadottak évi létszámának 1000-ről 1500 före való emelésébe. ${ }^{19}$

\section{Globális keresztes hadjárat?}

A mostani merénylet talán legaggasztóbb vonása, hogy tudatosan azzal a céllal követték el, hogy globális hatást érjenek el. Az esemény médiavisszhangját tekintve mostanra megállapítható, hogy ez valószínúleg sikerült is. Ha pedig a merénylet esetleg bosszúakciókra sarkall radikális iszlamistákat a világ más részein, akkor sajnos azt kell mondanunk, hogy Tarrant alapvetően elérte a célját.

Az új-zélandi merénylö úgy igyekezett feltüntetni magát, mint aki az iszlám elleni globális küzdelem része, élharcosa, s ugyanilyen küzdelemre igyekezett motiválni másokat is. Ebbe a globális ambíciószintbe illeszkedik az is, hogy a fegyvereit összefestette olyan személyek és helyszínek neveivel, akik és amelyek szerinte jelentős szerepet töltöttek be az iszlám elleni történelmi küzdelemben.

A nyugati sajtóban megjelent hírek szerint Tarrant a mostani merénylet elkövetése előtt néhány hónappal, 2018 őszén európai körútra indult. ${ }^{20}$ Azt tervezte, hogy végigjárja mindazon helyszíneket, ahol az oszmán török, illetve más muszlim csapatok valaha jelentősebb vereséget szenvedtek. Így került a fegyverre a 732-es tours-i ütközet (az ütközet Magyarországon poitiers-i csataként ismert), Martell Károly, Szkander bég, az oszmánok ellen harcoló albán nemzeti hős, valamint Hunyadi János, a lengyel Feliks Kazimierz „Szczęsny” Potocki, illetve Bécs 1683-as, sikertelen török ostroma, valamint a Sipkaszoros neve is, emléket állítva az oszmánok elleni nagy bolgár győzelemnek. ${ }^{21}$ Tarrant $^{2}$ Magyarországon is járt, ennek részleteit jelenleg a hatóságok vizsgálják, együttműködve más országok bünüldöző szerveivel. ${ }^{22}$

Tarrantot azonban nemcsak a történelmi példák, hanem a kortárs elödök is vonzották. Sokatmondó, hogy feltüntette a fegyverén Alexandre Bissonette, a quebeci lövöldöző nevét is, manifesztumában pedig egyértelműen Anders Breiviket nevezte legfontosabb példaképének.

\section{A norvég tömeggyilkos mint minta}

Emlékezetes módon Anders Behring Breivik 2011. július 22-én először gépkocsiba rejtett, házi készítésü bombát robbantott a norvég főváros, Oslo kormányzati negyedében, melynek következtében nyolcan meghaltak, több mint kétszázan pedig megsebesültek.

19 Refugee quota to rise from 1000 to 1500, [online], 2018. 09. 21. Forrás: radionz.co.nz [2019. 03. 15.]

20 Jovana Gec: New Zealand gunman entranced with Ottoman sites in Europe, [online], 2015. 05. 16. Forrás: washingtonpost.com [2019. 03. 22.]

21 Ian Miles Cheong: Christchurch attacker livestreamed shooting spree, posted manifesto to 8chan, [online], 2019. 03.15. Forrás: lulz.com [2019. 03. 20.]

22 TEK: Vonattal járt Magyarországon az új-zélandi terrorista, [online], 2019. 03. 18. Forrás: hvg.hu [2019. 03. 22.] 
Alig másfél órával később az oslói merénylő a norvég fővárostól 40 kilométerre fekvő Utøya szigetén, a kormányzó Munkáspárt ifjúsági táborában 69 embert lőtt agyon, s további 66-ot megsebesített egy Rutger Mini-14 félautomata puskával és egy Glock 17-es pisztollyal.

Breivik három szempontból különleges a nemzetközi terrorizmus történetében. Egyrészt azon kevés magányos elkövetök közé tartozik, akik ún. stratégiai jellegü - tehát nagy áldozatszámmal járó, nagy médiafigyelmet kiváltó és nagy félelmet gerjesztő - terrortámadásokat voltak képesek végrehajtani. Másrészt magányos elkövetőként szokatlanul részletesen (több mint 1500 oldalon) dokumentálta ideológiai és technikai felkészülését a merényletekre. Végül harmadrészt, a norvég tömeggyilkos azok közé a szintén igen ritka magányos terroristák közé tartozik, akik ideológiai hagyatékkal is rendelkeznek. ${ }^{23}$ A Breivik által képviselt ideológia eredetét tekintve olyan erős konspiratív és paranoid elemekben bővelkedő „ultrakonzervatív, szélsőjobboldali, nacionalistaként” írható le, amely a keresztény és az iszlám kultúrkör elkerülhetetlen küzdelmét vizionálja a 21. századi Európában. ${ }^{24}$

Tarrant mintakövető magatartását több tény is mutatja. Egyrészt saját, interneten közzétett kiáltványa, amelyben többször is hivatkozik Breivikre. Másrészt, hogy a nyomozás eddigi adatai szerint feltételezhető, hogy Tarrant - Breivikhez hasonlóan - gépkocsiba rejtett bombát is készített. ${ }^{25}$ Végül harmadrészt, többek szerint a bíróság elötti első szereplésével is Breivik példáját igyekezett követni (mosolyogva jelent meg a tárgyalóteremben és nem kért védöügyvédet). ${ }^{26}$ Ugyanakkor annak alapján, hogy Ardern miniszterelnök még Tarrant nevét sem hajlandó kimondani, hogy ne adjon neki extra publicitást, ${ }^{27}$ azt valószínűsíthetjük, hogy az új-zélandi hatóságok igyekeznek majd minden rendelkezésükre álló eszközzel korlátozni, hogy Tarrant a saját nézetei propagálására használhassa a bírósági tárgyalását.

A The Great Replacement című manifesztumában Tarrant egy szimbolikus és szélsőjobbos összeesküvés-elméletet, illetve rasszista újpogány ideológiát fejt ki, amelynek legfőbb célja a dzsihádizmussal szembeni harc. ${ }^{28}$ Jóllehet Brenton Tarrant valószínűleg magányos

23 Lásd például: Anders Behring Breivik: 2083 - A European Declaration of Independence, [online], 2011. Forrás: archive.org [2019. 03. 15.]

24 TÁLAs Péter - CsıKI Tamás: Az oslói/utøyai merényletről, [online], ZMNE SVKK Elemzések, 2011/8. Forrás: svkk.uninke.hu [2019. 03. 15.]

25 Jenny AwFord: Sole Christchurch gunman was about to attack again as he was arrested in bomb-rigged car after opening fire on two mosques, [online], 2019. 03. 20. Forrás: thesun.co.uk [2019. 03. 22.]

26 Asne Seierstad: The Anatomy of White Terror, [online], 2019. 03. 18. Forrás: nytimes.com [2019. 03. 22.]

27 Kalla WAHLQUist: Ardern says she will never speak name of Christchurch suspect, [online], 2019. 03. 19. Forrás: theguardian.com [2019.03. 22.]

28 Sasha Polakow-Suransky - Sarah Wildman: The Inspiration for Terrorism in New Zealand Came From France, [online], 2019. 03. 16. Forrás: foreignpolicy.com [2019. 03. 19.]; Mike WendLING: Christchurch shootings: The rising new threat of far-right violence, [online], 2019. 03. 18. Forrás: bbc.com [2019. 03. 22.]; TóтH Gergely: A tükörbe néznek, és egy templomos lovag néz vissza rájuk, [online], 2019. 03. 19. Forrás: index.hu [2019. 03. 22.]; Mehmet OzALP: The ideology behind Brenton Tarrant's terror attack poses a threat to us all, [online], 2019. 03. 19. Forrás: abc.net.au [2019. 03. 22.] 
elkövetőként vonul be a nemzetközi terrorizmus történetébe, számos elemzés arra hívja fel a figyelmet, hogy a christchurchi támadás a szélsőjobboldali, fehér, újnacionalista terrorizmus utóbbi években veszélyesen növekvő aktivitást mutató trendjéhez kapcsolható. ${ }^{29}$

\section{FELHASZNÁLT IRODALOM}

2013 Census QuickStats about culture and identity, [online], 2014. 04. 15. Forrás: stats.govt.nz [2019. 03. 15.] 2013 Census QuickStats about culture and identity, [online], 2014. 04. 15. Forrás: stats.govt.nz [2019. 03. 15.] Armstrong, John: Reality behind the Rainbow Warrior outrage, [online], 2005. 07. 02. Forrás: nzherald. co.nz [2019. 03.15.]

AwFORD, Jenny: Sole Christchurch gunman was about to attack again as he was arrested in bomb-rigged car after opening fire on two mosques, [online], 2019. 03. 20. Forrás: thesun.co.uk [2019. 03. 22.]

BREIVIK, Anders Behring: 2083 - A European Declaration of Independence, [online], 2011. Forrás: archive. org [2019. 03. 15.]

Bomb damage to the Wanganui Computer Centre, 1982, [online], 2012. 06. 20. Forrás: teara.govt.nz [2019. 03. 15.]

Cheong, Ian Miles: Christchurch attacker livestreamed shooting spree, posted manifesto to 8chan, [online], 2019. 03. 15. Forrás: lulz.com [2019. 03. 20.]

Facts about New Zealand's Muslim minority - a mere 1pc of the population, [online], 2019. 03. 15. Forrás: dawn.com [2019. 03. 15.]

FAULL, Jennifer: Facebook removed 1.5m videos of Christchurch attacks within 24 hours, [online], 2019. 03. 17. Forrás: thedrum.com [2019. 03. 20.]

Foroutan, Yaghoob: Muslim Minority of New Zealand in Global Context: Demographic Perspective, Journal of Muslim Minority Affairs, 37. évf. 2017/4, 511-519. o. DOI: https://doi.org/10.1080/13602004.2 017.1399599

GEC, Jovana: New Zealand gunman entranced with Ottoman sites in Europe, [online], 2015. 05. 16. Forrás: washingtonpost.com [2019.03.22.]

Holden, Michael: Britain is facing serious far-right terrorism threat, says top UK officer, [online], 2018. 02. 26. Forrás: reuters.com [2019. 03. 22.]

Holden, Michael: Man who drove van into London mosque worshippers jailed for 43 years, [online], 2018. 02. 02. Forrás: reuters.com [2019. 03. 16.]

Horton, Alex: 'This is what leadership looks like': U.S. Democrats Rally and New Zealand bans military-style guns, [online], 2019. 03. 21. Forrás: washingtonpost.com [2019. 03. 22.]

HunT, Tom: Trades Hall bombing tragedy still an unsolved mystery, [online], 2016. 03. 30. Forrás: stuff.co.nz [2019. 03. 15.]

LOWERY, Wesley - KINDy, Kimberly - BA TrAN, Andrew: In the United States, right-wing violence is on the rise, [online], 2018. 11. 25. Forrás: washingtonpost.com [2019. 03. 22.]

Ozalp, Mehmet: The ideology behind Brenton Tarrant's terror attack poses a threat to us all, [online], 2019. 03. 19. Forrás: abc.net.au [2019. 03. 22.]

Paris mosque: Man held after ,trying to ram crowd with vehicle', [online], 2017. 06. 29. Forrás: bbc.com [2019. 03. 18.]

Polakow-Suransky, Sasha - Wildman, Sarah: The Inspiration for Terrorism in New Zealand Came From France, [online], 2019. 03. 16. Forrás: foreignpolicy.com [2019. 03. 19.]

29 Michael Holden: Britain is facing serious far-right terrorism threat, says top UK officer, [online], 2018. 02. 26. Forrás: reuters.com [2019. 03. 22.]; Luiz RoMERo: US terror attacks are increasingly motivated by right-wing views, [online], 2018. 10. 24. Forrás: qz.com [2019. 03. 22.]; Wesley LOWERY - Kimberly KINDY - Andrew BA Tran: In the United States, right-wing violence is on the rise, [online], 2018. 11. 25. Forrás: washingtonpost.com [2019. 03. 22.]; Why white nationalist terrorism is a global threat, [online], 2019. 03. 21. Forrás: economist.com [2019. 03. 22.] 
Porter, Tom: Someone claiming to be the New Zealand mosque gunman posted a racist manifesto online before the attack, [online], 2019. 03. 15. Forrás: theinsider.com [2019. 03. 22.]

Refugee quota to rise from 1000 to 1500, [online], 2018. 09. 21. Forrás: radionz.co.nz [2019. 03. 15.]

RIGA, Andy: 'What I did is unforgivable,' Quebec mosque shooter says after pleading guilty, [online], 2018. 03. 28. Forrás: montrealgazette.com [2019. 03. 18.]

Romero, Luiz: US terror attacks are increasingly motivated by right-wing views, [online], 2018. 10. 24. Forrás: qz.com [2019. 03. 22.]

Schlicht, Martin: German jailed for life for stabbing Egyptian woman, [online], 2009. 11. 11. Forrás: reuters. com [2019. 03. 16.]

Seierstad, Asne: The Anatomy of White Terror, [online], 2019. 03. 18. Forrás: nytimes.com [2019. 03. 22.]

Smith, Reiss - Kettley, Sebastian - Rogers, Jon - Kirby, Will: London terror attack TIMELINE: 4 dead and 29 injured after major incident at Westminster, [online], 2017. 03. 23. Forrás: express.co.uk [2019. 03. 24.]

Stop Islamophobia, [online], 2017. 08. 25. Forrás: elpais.com [2019. 03. 18.]

TÁLAs Péter - Csıкı Tamás: Az oslói/utøyai merényletről, [online], ZMNE SVKK Elemzések, 2011/8. Forrás: svkk.uni-nke.hu [2019. 03. 15.]

TAN, Lincoln: The state of faith: Muslims most likely to be unemployed, [online], 2015. 05. 14. Forrás: nzherald.co.nz [2019. 03. 15.]

TEK: Vonattal járt Magyarországon az új-zélandi terrorista, [online], 2019. 03. 18. Forrás: hvg.hu [2019. 03. 22.]

Tóтн Gergely: A tükörbe néznek, és egy templomos lovag néz vissza rájuk, [online], 2019. 03. 19. Forrás: index.hu [2019. 03. 22.]

WAHLQUIST, Kalla: Ardern says she will never speak name of Christchurch suspect, [online], 2019. 03. 19. Forrás: theguardian.com [2019. 03. 22.]

WendLING, Mike: Christchurch shootings: The rising new threat of far-right violence, [online], 2019. 03. 18. Forrás: bbc.com [2019. 03. 22.]

Why white nationalist terrorism is a global threat, [online], 2019. 03. 21. Forrás: economist.com [2019. 03. 22.]

Winterbotham, Emily: The Westminster attack shows the new challenges facing UK counter-terrorism, [online], 2017. 03. 24. Forrás: theguardian.com [2019. 03. 23.] 